\title{
The Features of Management Accounting in Appraisal Companies
}

\author{
Rashid Ruzanov ${ }^{1}$ \\ Aida Daniyar ${ }^{2}$ \\ ${ }^{1}$ Institute of Economics, Science Committee of the MES, Kazakhstan \\ rashid_ruzanov@mail.ru \\ 2University of International Business, Kazakhstan \\ aidaniyar@inbox.ru
}

\begin{abstract}
The aim of the study is to determine the specificity of management accounting in appraisal companies. Appraisal activity is one of the aspects of the multi-faceted concept of «appraisal», which also means the process of professional appraisal implemented by the appraiser, and applied economics with its own methodology, terminology, research principles, and professional opinion of the appraiser regarding the value of a particular object of appraisal. Methodology. This study uses a historical, systematic and integrated approach to the transfer of material. Transmission logic, which is the original definition of the basic concepts and further description of fundamentals of management accounting, allows understanding patterns and modern trends of appraisal activity.

Certain provisions were used in the practice of a Limited Liability Partnership engaged in appraisal services. Research results obtained allow us to understand the nuances of management accounting to improve the performance of appraisal companies in the Republic of Kazakhstan.

The scientific novelty of the research is that because of a theoretical study of management accounting, possible directions for increasing the wellness of appraisal companies are justified. Theoretical and practical significance of the study connect with the possibility of using the scientific results in the deals of the Ministry of Finance of the Republic of Kazakhstan and its structural subdivisions, the tax authorities at different levels, the Ministry of national economy of Kazakhstan. This fundamental research can be used as a basis for training specialists in the field of performance accounting.
\end{abstract}

Keywords: appraisal, management accounting, property, value, customers, costing. 


\section{Introduction}

In a market economy, management accounting and performance analysis based on its data are objectively necessary. Analysis using management accounting data is one of the main conditions that allow management to make the right management decisions, so the survival and success of any organization in a market economy with its inherent high competition is largely determined by the degree of development of management accounting in it.

Functionally developed management accounting, focused on a competitive environment, will make it possible to identify information and technological processes that are a priori focused on making informed and optimal management decisions that will allow timely elimination of shortcomings characteristic of accounting and financial accounting. The effectiveness of management control leads to the guarantee of reliable information in accounting (financial) statements, reliability, stability and security of the organization's assets, allows you to explore the relationship between management and tax accounting, thereby contributing to successful and profitable activities. In this regard, it is very important to develop theoretical and practical recommendations that are aimed at strengthening the role and importance of management accounting, improving the methodology of its organization.

The main changes in the demand for management accounting information characteristic of modern manufacturing companies are observed in many organizations that provide services, the role of which in the economy has significantly increased in the late XX century. In Kazakhstan's economy, against the background of traditional services to the population, such as household, communications, transport, housing and utilities, culture, tourism, medical, trade and public catering, new types of services are emerging: audit, consulting, insurance, trust, financial, freight and many others. The range of production services provided has a wide range: from the provision of electricity and communications to banking and appraisal services.

Management accounting refers to the process of measurement, identification, analysis, accumulation, interpretation, preparation and provision of financial, marketing, production and other information on the basis of which the company's management makes strategic and operational decisions. The management accounting system 
generates data in both monetary and physical terms. Management accounting not only registers the company's activity data, but also interprets the information received, providing it to the manager, who makes management decisions based on it (Amey and Egginton, 1973).

Management accounting, defining only the company's internal activities, is based on such economic processes as regulation, planning and forecasting. The most important functions that management accounting is responsible for in an organization can be expressed in the simplest scheme: providing information - analysis - planning motivation - coordination - control. They can be divided into two types: functions that are responsible for the exchange of information, and functions that guarantee its quality. The first is the implementation of an information exchange system, its provision, analysis, and planning of follow-up activities. To the second - motivation of personnel, coordination of activities of separate divisions and control over the proper implementation of the plan.

Management accounting provides management with information: profit calculation; income and expenses; inventory estimation; cost formation; justification of sales prices. Once the information has been received, it is carefully analyzed and prepared for decision-making. In the course of the analysis: the ways of the most appropriate use of resources are determined; investment policy is developed; information about the current assortment, output or sales volumes is prepared; the ability of the organization to further growth and development is identified. The received and analyzed information is the basis for the next function of management accounting - planning (2013). In accordance with it, the following activities are carried out: development of tactical and operational plans; preparing data for the formation of long and short term strategic development plans; developing projections.

Having a good understanding of the key value of the category «price» for the characterization of processes in the economic system, we come to the conclusion that the concept of «appraisal» as a complex indicator of the measure of significance, profitability, expediency of obtaining a particular result of activity, as well as the resources that provide this result (2003).

\section{Literature Review}


Analysis of the works of domestic and foreign authors indicates that the theoretical aspects of the impact of the role of management accounting on appraisal activities are not sufficiently explained and developed. In addition, there are no principles for proper management accounting in appraisal companies.

Issues of management accounting for appraisal activities were considered by Russian and foreign researchers as Demich and Buglova (2018); Ripoll-Zaragossky (2001); Allaverdyan (2014); Katsman, Kosorukova and Rodin (2008); Safaryan (2012); Helfert (2005); Grigoriev (2000); Zimin (2010); Popova (2011); Artemenkov and Artemenkov (2013).

In Kazakhstan, the specifics of appraisal activities are mainly reflected in «The law on appraisal activities of the Republic of Kazakhstan» (2018), in «The Rules on the application by entities of appraisal activities of requirements for methods of appraisal of real estate (with the exception of enterprises as property complexes)» approved by a joint order of the Minister of justice of the Republic of Kazakhstan (2018).

These works have made a significant contribution to the review of the theory, methodology and practice of formation and development of appraisal activities and proper management accounting. At the same time, many theoretical, methodological and practical aspects of developing and justifying the activities of appraisal companies in our country and in the world remain poorly studied.

\section{Methods}

The research methodology is based on General scientific methods of knowledge, principles and criteria of objectivity in their versatility and inconsistency, based on the totality of works of domestic and foreign scientists, statistical indicators that correspond to the truth and General laws of state and socio-political development at the historical stage under study.

\section{Sample}

The study used statistical sources of the statistical Agency, Ministry of Finance, Ministry of national economy of Kazakhstan, legislative acts of Kazakhstan, normative-legal documents regulating management accounting monographs and Internet sources on this issue. 


\section{Data collection}

The database of the research consists of legislative and regulatory acts of the Republic of Kazakhstan; data from statistics Committee of the Ministry of national economy; materials of scientific and research conferences and seminars; statistical information contained in scientific publications.

\section{Results and review}

Appraisal activities are an essential component in creating a developed infrastructure that is necessary for further economic transformation in our country. For a decade, the results of appraisal of various properties have been the basis for most decisions in the private and public sectors. Appraisal has become an integral tool in the arsenal of a modern businessman, financier, and manager. In a market economy, it is difficult for an ordinary citizen, a government official, a politician, and an entrepreneur to do without ideas about appraisal activities.

The appraisal objects include:

- All types of real estate.

- Means of transport.

- Securities.

- Intellectual property.

- Business.

- Machinery and equipment.

The purpose of the assessment for the appraiser is to prepare an opinion on a particular type of value to the customer, while acting as an independent, disinterested party to develop an unbiased opinion on the value of the object being appraised. Thus, from the point of view of the appraiser, there is only one goal, namely, to set the required value for the client. However, the appraiser must be familiar with the intended use of the appraisal report, since he must apply the theoretical and practical knowledge and techniques of appraisal relevant to this particular function in order to obtain a reasonable conclusion. Although the appraiser may choose a certain type of value (for example, market value, liquidation value) and apply various research methods, this choice should be based on knowledge of how the appraisal report will be used in the future and why the owner needs to know the value of their assets (Table 1). 
Table 1. The main goals of appraisal companies.

\begin{tabular}{|l|}
\hline Conducting contests, auctions \\
\hline Reporting, purchase and sale, exchange \\
\hline Lease, lease rights, leasing \\
\hline Pledge \\
\hline Division, inheritance, donation \\
\hline Insurance \\
\hline Privatization, confiscation, nationalization, liquidation \\
\hline Formulating a marriage contract \\
\hline Calculation of taxes, duties, and fees \\
\hline Determining the share of property rights \\
\hline Storage \\
\hline Resolution of property disputes \\
\hline Commercial concession \\
\hline Transfer of ownership \\
\hline Transfer to trust management \\
\hline
\end{tabular}

Like any system, the appraisal system must have integrity (all elements are interconnected), structure (each element is necessary in the system), purposefulness (there must be a goal for the functioning of the system as a whole), relationship with the external environment (the appraisal system does not function by itself, but in various connections with other subsystems of the economy).

Elements of the appraisal system include:

- legal entities and individuals (individual entrepreneurs) engaged in business activities (appraisers);

- individuals who are specialists in an appraisal;

- consumers of assessment services (public authorities, individuals and legal entities of all forms of ownership);

- educational and research organizations in the field of appraisal;

- self-regulating organizations of appraisers;

- organizations that provide information support for appraisal activities.

A clear understanding of the appraisal system, its main elements, the relationship between them, their functions and principles of operation are directly related to improving the functioning of the appraisal system as a whole. The features of appraisal 
activities that affect the organization of management accounting depend on the specifics of its technological process and organizational structure.

Technological features define two main components of accounting:

- direction of information collection;

- the method of cost accounting and calculating the cost of production (Safaryan, 2012). Features of the organization of accounting in the field of appraisal activities are primarily due to the fact that the appraisal service can be considered as a general production process, in which it is possible to distinguish its components. They are technological processes that are pre-planned operations. In this case, the organization determines how business processes will be the objects of planning and accounting activities. This will allow to identify the responsibility centers in the context of which information is collected (Hopper, 1980).

All the technological processes shown in the figure 1 are part of the overall technological process, so it can be noted that auxiliary activities are not represented in the appraisal business. The results of the analysis of the company's organizational structure help to determine the main directions of the company's economic activity, the cost structure, the list of responsibility centers, their structural composition and budgeting features, as well as the responsibilities of managers. For example, the budgeting feature of the management cost center is the preparation of cost estimates, and for the sales department, when forming the sales budget, revenue planning is used.

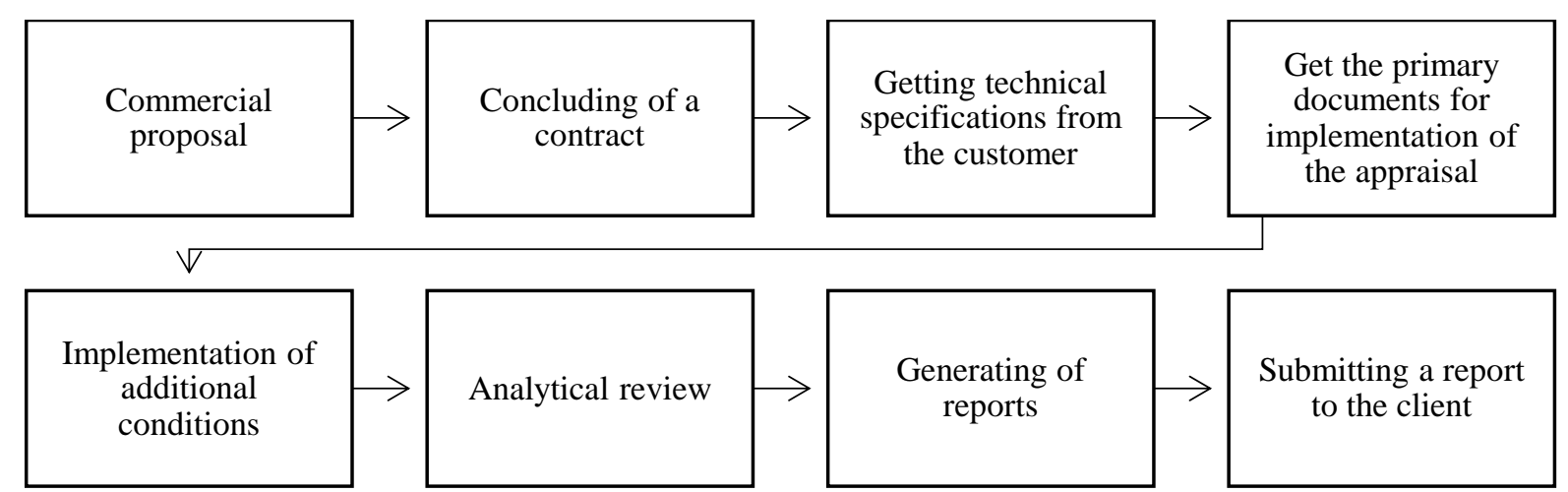

Figure 1. Technological processes that make up the appraisal service.

An important component of reflecting the characteristics of the appraisal activity is the applied methods of cost accounting and calculating the cost of production, in particular: - cost accounting object; 
- completeness of recorded costs;

- efficiency of cost accounting and control (accounting for actual and standard costs).

The object of cost accounting directly depends on the characteristics of the production process. For example, the features of appraisal activities serve as the basis for applying the order-based method of cost accounting. Accordingly, the object of cost accounting in the appraisal activity is an order, i.e. a specific appraisal service (Rutgizer, 2005).

Initially, the planned cost price is calculated for each order (project, contract), which is formed by calculating the average cost rates for the service provided. Here, the choice of the calculation unit that will characterize the individual cost of this service is of great importance. In relation to appraisal activities, it is customary to choose units of time as the calculation unit, namely, the man-hours of specialist appraisers. Working time of employees is the main resource of an appraisal company, and the ability to manage it effectively can be a competitive advantage, a way to reduce the cost of services. This is the main feature of the appraisal activity, on which the entire organization of management accounting depends.

Other units, such as the number of reports, regardless of the time spent on them, cannot be used in the analysis of the performance of the appraisal company. In companies that provide assessment services, it is advisable to organize the accounting of employees ' working hours in a special program, in which employees will daily enter data on the work they have done during the day.

Currently, such programs are already widely represented on the market of the country. In addition, a major appraisal of the company independently develops similar programs tailored to business. There are also special primary accounting documents that reflect the specifics of accounting, such as time sheets, which are filled in if the information is entered into the program not by each specialist appraiser, but by one employee based on the accounting sheets presented to him by appraisers, statements of the structure of working hours, calculation of additional remuneration and bonuses, and based on such information collected from all departments (appraisers) for a certain period of time, it is possible to: analyze the structure of the appraisers ' working hours, their effectiveness; calculate the standard hour of the appraiser, which will help to determine the planned cost of the appraisal service. 
The incomplete actual cost (direct costing) of the service rendered is formed based on the calculation data after completion of all work for each specific order, so until the order is completed, all costs related to it are considered as work in progress.

\section{Conclusion}

In general, the management accounting system for production costs should allocate costs to two main groups of objects: divisions and products. Within the framework of budget planning, planned (budget) and actual indicators are recorded. The completeness of the recorded costs and the efficiency of accounting and control over them characterize the degree of detail of information about costs for the purposes of management accounting and analysis.

\section{References}

Mikerin, I. L. and Artemenkova, I. L. International standards of evaluation 2011. (2013). Moscow: Russian society of appraisers. 188.

Allaverdyan, V. (2014) Features of the national valuation activity. Accounting and banks. 5, 16-19.

Amey, L.R. and Egginton, D.A. (1973) Management Accounting: A Conceptual Approach. Longman, Harlow, Essex.

Boyns, T. and Edwards R. A. (2013). History of Management Accounting: the British Experience. NewYork: Routledge.

Davidenko, N. and Kudashev, A. (2003). Financial management: evolution of views and refinement of the subject. Problems of management theory and practice. 1, 116118.

Demich, I.E. and Buglova P.A. (2018). Comparative analysis of methods for assessing potential bankruptcy. Politics, Economics and Innovations. 3 (20), 16.

Grigoryev, V.V. (2000). Enterprise Valuation. Property approach. $2^{\text {nd }}$ ed. Moscow: Delo.

Helfert, E. (2005) Technique of financial analysis. Moscow: Peter.

Hopper, T.M. (1980). Role conflicts of management accountants and their position within organization structures, Accounting, Organizations and Society. 5, 401-412. 
Katsman, V.E., Kosorukova, I.V. and Rodin A.Yu. (2008). Evaluation Activities: Legal, Theoretical, and Mathematical Foundations. Moscow: LLC Market DS Corporation.

Korostelev, S.P. (2020). Problematic issues of the theory and practice of real estate valuation at the present stage. Retrieved from https://mirznanii.com/

Popova, L.V. (2011). Assessment and taxation of real estate and other property of enterprises: methods and practice. Moscow: Business and Service. 240.

Ripol-Zaragooci, F. B. (2001). Fundamentals of valuation activity. Moscow: PRIOR.

Rules for the application of requirements to methods of valuation of real estate (except for enterprises as property complexes) by subjects of appraisal activity. (2002) Approved by joint order of the Minister of justice of the Republic of Kazakhstan dated 1 November 2002 No. 173 of the Minister of Finance of the Republic of Kazakhstan dated 2 December 2002, No. 600, Minister of industry and trade of the Republic of Kazakhstan from November 26, 2002, № 96, Chairman of the Agency for land resources management of the Republic of Kazakhstan dated 23 November 2002, No. 90. Retrieved from https://online.zakon.kz/

Rutgizer, V.M. Interdisciplinary Issues of Cost Estimation. (2005). Moscow: QuintoConsulting Publishing House, 6-12.

Safaryan, K.V. (2012). Evaluation activity: concept, regulatory framework, regulatory mechanisms. Laws of Russia: experience, analysis, practice. 8, 3-9.

The Law of the Republic of Kazakhstan (2018) No. 133-VI On Appraisal Activities in the Republic of Kazakhstan. Retrieved from https://online.zakon.kz/.

The Law (2018). On appraisal activity in the Republic of Kazakhstan.

Zimin, A.I. (2010). Property Valuation: Questions and Answers. Moscow: Jurisprudence. 